\title{
THE PROGNOSIS FOR THE CONTRALATERAL LUNG AFTER RESECTION FOR PULMONARY TUBERCULOSIS
}

\author{
BY \\ M. R. GEAKE AND F. H. YOUNG \\ From the Brompton Hospital, London
}

(RECEIVED FOR PUBLICATION DECEMBER 15, 1952)

Comparatively little attention has been paid to the factors affecting the fate of the contralateral lung after resection for pulmonary tuberculosis. In particular, the previous history of the patient and his reaction to the tubercle bacillus and the radiological history of the lung, as opposed to the extent of disease at the time of the operation, have been the subject of very little analysis. We have studied these factors in the cases chosen by the physicians of the Brompton Hospital and accepted by their surgical colleagues for resection during the years 1949 and 1950. At the time of our analysis a minimum period of 15 months had elapsed since operation. All patients who have been traced satisfactorily are the subject of this communication. For certain purposes the records of an additional 31 patients who underwent resection at Brompton Hospital during the same period but had not been under the care of the Brompton Hospital physicians have also been included.

The records of 101 patients who had survived the immediate post-operative period (three months) were available for study. Their fate and the condition of the contralateral lung at the end of the follow-up period are shown in Table I. In only 11 was the contralateral lung considered to be unsatisfactory. By "unsatisfactory" we mean that a deterioration had taken place during the follow-up period. Hence "satisfactory" means unchanged or improved without intermediate deterioration. Of the six patients who died after the postoperative period (three months), five had satis-

TABLE I

CONDITION OF OPPOSITE LUNG AT END OF FOLLOW-UP PERIOD OR AT DEATH IN 101 PATIENTS AFTER LUNG PERIOD OR AT DEATH IN 101 PATIENTS AFTER
RESECTION AND SURVIVAL FOR 3 MONTHS

\begin{tabular}{l|c|c|c|c|c}
\hline & \multicolumn{2}{|c|}{ Late Deaths } & \multicolumn{2}{c|}{ Survivals } & \\
\cline { 2 - 3 } & $\begin{array}{c}\text { Condition of } \\
\text { Opposite Lung }\end{array}$ & $\begin{array}{c}\text { Condition of } \\
\text { Opposite Lung }\end{array}$ & Total \\
\cline { 2 - 4 } $\begin{array}{c}\text { Satis- } \\
\text { factory }\end{array}$ & $\begin{array}{c}\text { Unsatis- } \\
\text { factory }\end{array}$ & $\begin{array}{c}\text { Satis- } \\
\text { factory }\end{array}$ & $\begin{array}{c}\text { Unsatis- } \\
\text { factory }\end{array}$ & \\
\hline $\begin{array}{l}\text { Pneumonectomy } \\
\text { Lobectomy }\end{array}$ & 2 & 1 & 53 & 8 & 64 \\
\hline
\end{tabular}

factory contralateral lungs, and in one a deterior ation was shown by the radiograph shortly beforedeath. In these five it seems reasonable to supposes that if the condition of the lung submitted to oper-은 ation had remained good the opposite lung wouldhave remained satisfactory. Of the 95 patients alive at the present time 72 were followed up for the full two years. In these only one rather doubtful spread occurred after 15 months, thes minimum follow-up period. Of the 11 cases in which deterioration was noted, it occurred withino six months in two, within 12 months in eight, and after 15 months in the other as already stated Accordingly it seems that deterioration in the con? tralateral lung if connected with the resection wilp probably appear within 12 months, and hence th $\vec{E}$ cases followed for the shorter times can reasonably be included with those followed for the full two years.

The selection of cases by a number of physicianst makes it certain that the group was widely repre을 sentative both in the type of case and in the imporx tant factor of duration of the pre-operative treat? ment.

We have tried to find out if there were an factors in the clinical or radiological history which made deterioration in the contralateral lung espec은 ally likely. We have analysed the previous radiop logical history of the extent of disease in the resected lung, the pre-operative amount of sputunfor the length of history, and the ages and sex, with the following results.

Previous Condition of Lung.-." Spreads" of disease may of course result from the exacerbation of an existing focus or from the appearance of new area of disease. It is impossible to diagnose the latter with certainty because a pre-existing focus may have been present but not susceptible to radiological diagnosis. Hence it is useless to tiत to distinguish between the two types of spread.

The 101 cases were divided into three groups of the basis of the radiographic appearances of the other lung up to the time of operation: (1) Cass in which no disease had ever been apparent. 
TABLE II

PROGRESS OF OPPOSITE LUNG AFTER RESECTION FOR PULMONARY TUBERCULOSIS RELATED TO ITS PREVIOUS CONDITION

\begin{tabular}{l|c|c|c|c}
\hline & \multicolumn{2}{|c|}{ State of Opposite Lung before Operation } \\
\cline { 2 - 4 } & $\begin{array}{c}\text { No } \\
\text { Disease }\end{array}$ & $\begin{array}{c}\text { Disease } \\
\text { Active } \\
\text { within } \\
\text { Previous } \\
12 \text { Months }\end{array}$ & $\begin{array}{c}\text { Static } \\
\text { Disease }\end{array}$ & Total \\
\hline $\begin{array}{l}\text { No. of cases .. } \\
\text { No. with unsatisfac- } \\
\text { tory post-operative } \\
\text { changes in opposite } \\
\text { lung }\end{array}$ & 51 & 22 & 28 & 101 \\
\hline
\end{tabular}

Cases in which during the previous 12 months new disease had appeared, or unfavourable changes had occurred in old. (3) Cases in which disease had remained unchanged or had become less during at least the 12 months before the operation. The progress of the opposite lung in these three groups is shown in Table II. It was found that deterioration was much commoner in cases in which unfavourable changes had taken place in the 12 months preceding the operation. Combining the groups with no previous or static disease, five out of 79 , or $6.3 \%$, showed deterioration, as against $27.3 \%$ for those with recently active disease ; this difference $(21 \%)$ is significant (S.E. 9.9\%). The numbers are too small for comparison between cases with no previous and with static disease.

Amount of Sputum.-The quantity of sputum measured pre-operatively might be expected to have a bearing on early post-operative spreads, but resection holds promise of mitigating the late effects. Table III analyses the late post-operative spreads in relation to the pre-operative daily amount of sputum.

\section{TABLE III}

LATE POST-OPERATIVE SPREADS IN RELATION TO PRE-OPERATIVE DAILY SPUTUM VOLUME

\begin{tabular}{|c|c|c|c|}
\hline $\begin{array}{l}\text { Pre-operative Dail } \\
\text { of Sputum ( }\end{array}$ & Amount & No. of Cases & No. of Spreads \\
\hline $\begin{array}{l}\text { Less than } 1(30 \mathrm{ml} .) \\
1-2(30-60 \mathrm{ml} .) \\
\text { More than } 2(60 \mathrm{mi} .)\end{array}$ & $\because$ & $\begin{array}{l}50 \\
20 \\
31\end{array}$ & $\begin{array}{l}4(8 \%) \\
3(15 \%) \\
4(13 \%)\end{array}$ \\
\hline
\end{tabular}

The cases with little or no sputum appear to have fared better than those with a large amount of sputum. There were $8 \%$ of spreads in the first group compared with $14 \%$ in the combined groups who had more than $1 \mathrm{oz}$. ( $30 \mathrm{ml}$.) of sputum daily, but this difference is not statistically significant.

LENGTH OF History of Tuberculosis.-The length of history of tuberculosis in any case might be expected to influence the prognosis in several ways. A long history suggests extensive disease which is the most clearly proved factor in prognosis, but on the other hand the fact that a patient with long-standing disease is considered fit for resection suggests a high resistance. This series includes a high proportion of old-standing cases, and the results are not necessarily applicable to cases with short histories.

TABLE IV

LATE POST-OPERATIVE SPREADS IN RELATION TO KNOWN DURATION OF DISEASE

\begin{tabular}{|c|c|c|}
\hline & Cases & No. of Cases Deteriorating \\
\hline \multirow[t]{2}{*}{$\begin{array}{ccc}\text { History less than } 1 \text { year } & \ldots \\
, " & 1-2 \text { years } \ldots & \ldots \\
, & 2-3 \text {, } & \\
, & \text { more than } 3 \text { years }\end{array}$} & $\begin{array}{l}8 \\
19 \\
15 \\
59\end{array}$ & $\begin{array}{l}0 \\
2(10 \cdot 5 \%) \\
2(13 \cdot 3 \%) \\
7(11 \cdot 8 \%)\end{array}$ \\
\hline & 101 & $11(10.9 \%)$ \\
\hline
\end{tabular}

Table IV analyses the incidence of late postoperative spreads in relation to the known duration of the disease. There was little difference in the numbers of such spreads in the cases with probable durations of one to two years, of two to three years, and of more than three years. The number of cases in the very short history group is too small to allow deductions to be drawn.

Age AND SeX.- On analysis of the data by age and sex groups, no significant variation in incidence of spreads was found between the age-groups below 25 years, 25 to 40 years, and 40 to 50 years. Of the four patients over 50 years of age, no fewer than three showed late spreads in the opposite lung, but no conclusions can be based upon such a small number of observations.

\section{SUMMARY}

The radiological after-histories of 101 patients with pulmonary tuberculosis who had been treated by lung resection have been examined to try to elucidate factors leading to later deterioration in the contralateral lung.

Deterioration occurred in $11 \%$ of 101 patients who survived more than three months after operation. It was more frequent with disease of recent origin in the contralateral lung, but this did not apply to old-standing disease and possibly in those with a large amount of sputum.

No evidence was discovered that the extent of disease in the resected lung or length of history had any appreciable influence.

Where deterioration is going to take place, it is probable that it will do so within the 12 months following the operation.

We wish to express our gratitude to our colleagues at the Brompton Hospital who have allowed us to use the notes and radiographs of their patients. 